\title{
Emotional Mindsets of Millennial Consumers in Surabaya on Local Indie Brands Purchase Decision \\ Harti Harti
}

Faculty of Economics, Universitas Negeri Surabaya, Surabaya, Indonesia

\section{Abstract}

Emotions are the main drivers in the whole process of decision-making. In this online consumption era, many products try to offer experiences that speak to the emotions of customers and facilitate confident purchase decisions, one of which is products from local indie brands. As local indie brands are now popular among the millennial, to help drive sales and loyalty to their products, it is important to know the key emotional drivers and factors in the needs, desires, and behaviors of the consumers. This quantitative study that was conducted on 185 millennials in Surabaya aims to analyze eight different emotional mindsets that influence how millennial consumers

Corresponding Author:

Harti Harti

harti@unesa.ac.id

Received: 29 January 2019

Accepted: 27 February 2019

Published: 24 March 2019

Publishing services provided by Knowledge E

(c) Harti Harti. This article is distributed under the terms of the Creative Commons

Attribution License, which permits unrestricted use and redistribution provided that the original author and source are credited.

Selection and Peer-review under the responsibility of the $3 \mathrm{rd}$ ICEEBA Conference Committee. make decisions to shop and buy. These eight emotional mindsets include: Know-lt-All, Need Validation, Got to be First, Some Fun Want, Avoid Remorse, Decision Anxiety, I am Special, Buy and Be Done. The findings show that Need Validation is the most significant factor that influence the decision to purchase local indie brand products. This research will help these brands to be able to plan personalized and optimized shopping experiences that resonate with buyers, hence, increase their competitiveness.

Keywords: emotional mindsets, millennial consumer, local indie brand, purchase decision

\section{Introduction}

Recently there has been a period in which the development of information technology has led to the development and growth of the digital economy. The presence of a digital economy is caused by the ease of access to information, innovation and problem solving that is faster, easier and cheaper. This has provided space for creativity to the public, especially from startups and budding entrepreneurs, whose creativity starts to disrupt large companies or disrupt the established brands.

The data [1] shown that the number of startups in Indonesia is ranked sixth in the world with 1924 startups and the entrepreneurial ratio to Indonesia's population rose to $3.1 \%$ in 2017 from 1.67\% in 2014 [2]. Some of these novice entrepreneurs produce products with brands independently, not large-scale, and often different from mainstream products 
of established and well-known brands. Their brands are often known as indie brands, which are niche oriented.

Consumption of indie brand products lately has become a popular culture among millennials, especially since the rise of social media and e-commerce in this digital age, even a campaign movement arose to 'buy and support local products' and was considered a cool thing. 'Local-ness' is a self-justification of the indie scene. Millennials are those generations born between the 1980s and 2000s, when sophisticated ICTs, mobile devices and the internet were introduced to the public. Millennial generation at this time, has entered the productive age of work and is included in the category of adult consumers. Millennials in Surabaya are especially digitally savvy with need of constant connectivity, and highly spend their time on the internet engaging in heavy social media usage and e-commerce [3].

The high use of the internet to access social media and e-commerce, encourages the presence of products with independent brands and its online marketing activities. Thanks to online marketing, indie brands collectively, are able to shift established brands that have a good positioning on the market. With the increasing number of indie products in the market, and the more easily producers and consumers to access information technology, consumers have more opportunities to compare products or brands, and also consider their purchase options. Therefore, marketers, both online and offline, are now looking for solutions to break through, and meet Millennials' expectations and experiences, which are determined by digital connectivity.

Many factors influence consumers to buy. One of the factors that influence it is the mental set of emotional mindsets. This emotional mindset will lead a person in deciding their purchase [4]. Therefore, this study seeks to explain and analyze the key emotional drivers and factors in the needs, desires and behaviors of the consumers, that influence how millennial consumers make decisions to shop and buy.

\section{Literature Review}

\subsection{Local Indie brands}

Indie culture in general, is better known as a mainstream challenger. The indie word itself comes from the word 'independent' which implies small-scale industries with low budget and niche oriented, personal, artistic and creative. 'Indie' is artsy, offbeat, unusual, autonomous and provocative; 'Mainstream' implies a large-scale commercial industry that values money more than art [5]. In the scene of Indonesian indie clothing and 
fashion, it refers to small, independent, and often collectively owned shops that produce and sell their own clothing lines along with items produced by their larger network of connections within the scene [6].

However, indie now has become a buzzword, which means uncompromising, edgy, hip, or alternative, far beyond the literal designation of products made independently from large companies. Indie brands refers not only to physical goods such as clothing, cosmetics, books, hotels, food and beverages, but also to movies, music, and other forms of cultural expression. It includes social groups that cluster around these forms and the practices of entrepreneurship that produce and disseminate them [5]. Indonesian indie brands themselves now become 'luxury' items in Indonesia, and often sold in upscale shopping centers for prices that compete with those of international labels [6].

\subsection{Purchase decisions}

According to Kotler [7] there are five stages of consumer purchase which include problem recognition, information search, evaluation of alternatives, purchase decision, and post-purchase behavior. While Smith [4] mentions there are six stages of purchasing, namely inspiration, research, purchase, delivery, return, post-purchase.

\subsection{Aspect of emotional mindsets of consumers}

Psychologically, consumers have an aspect of mindset that is consciously or unconsciously formed by the environment or learning. Learning can come from stimuli that are then responded to by consumers, where each consumer has a different response rate. If information or stimulus is received continuously, it will be able to form a mindset. Mindset is that which is embedded in the mind, which manifests a pattern of behavior. In this case it is a pattern of buying behavior.

Consumers in their buying behavior cannot be separated from the emotional involvement in themselves, even though the purchase is taken rationally, there is still the possibility of containing a little emotional element. On the other hand in purchasing decisions, a consumer is influenced by both rational and emotional elements. However, with the amount of information and influential environment, consumers can become emotional in deciding on their purchases. For example when deciding to buy a car, although the reason for buying a car has been considered rationally, but there is still an emotional element for example in choosing the color or design of the car. 
Smith [4] recommends eight consumer emotional mindsets in purchasing decisions, namely: (1) Know It all, (2) Need validation, (3) Got to be First, (4) Want some Fun, (5) Avoid remorse, (6) decision anxiety, (7) I am special, (8) Buy and be One.

1. Know It all is: "I'm shopping for information more than I am actually buying something."

2. Need validation is: "I'm shopping by opinions - yours, mine, his, hers.. everybody's opinion."

3. Got to be First is: "I shop and buy cool." A consumer will tend to feel happy to be the first buyer, and will be proud if he can convey to friends or share on social media.

4. Want some fun is: "Shopping is a hobby and I like to have fun".

5. Avoid remorse is: "Shopping is a chore for me. I'm looking to buy on the most fast, trusted path."

6. Decision anxiety is: "I get overwhelmed when I shop. I want to take my time."

7. I'm special is: "I expect the product and shopping experience to be top of the line."

8. Buy and be One is: "I get easily frustrated when I shop because I don't get why I need all these extra ways to shop."

\section{Methodology}

Based on the research objectives, this research was carried out using quantitative methods, with multiple linear regression analysis techniques. The population in this study is the millennial generation in Surabaya. Surabaya was chosen as the object of research because Surabaya as an urban center and business center in East Java. However, observations are made based on online or digital-based buying behavior. A sample of 184 people was taken. The analysis of survey data, using linear regression analysis, which processed by using SPSS software. The dependent variable is Purchase Decision of Local Indie Brands, and the independent variables are: (1) Know It all, (2) Need validation, (3) Got to be First, (4) Want some Fun, (5) Avoid remorse, (6) decision anxiety, (7) I am special, (8) Buy and be One. 


\section{Findings and Discussion}

Emotional minds as a whole, have a significant influence on purchasing decisions of indie brands. But partially only Need Validation has a significant effect with significant value of 0.005 . While other emotional minds, such as Know It all, Got to be First, Want Some Fun, Avoid Remorse, Decision Anxiety, I am special, Buy and be One, have no significant effect. The results of this study indicate that millennial consumers consider the review, and opinions of others. Millennial consumers in the buying decision process are more influenced by online references. Before deciding to buy, millennials tend to pay more attention to information on the internet, both websites and social media.

The existence of an online review is very significant impact on the minds of millennials who almost every time update social media. Even the results of this study prove that, consumers decide to buy indie products because of their confidence in choosing local indie brand products because the reviews and opinions of people about the product are interesting, so consumers are influenced to buy. Millennials are more educated on products than any other generation before them. They are going online and getting their recommendations from real people. Celebrities are not as important anymore in the marketing.

While it can be explained why Know It all, Got to be First, Want some Fun, Avoid Remorse, Decision Anxiety, I am special, also Buy and be One, does not affect the decision to buy indie brands. Explanation as follows:

Know it all is to find as much information as possible about something that will be purchased. The insignificant findings prove that millennial consumers don't like to spend time searching for too much information, they prefer to immediately see other people's reviews. If it is associated with Need Validation, then consumers actually do not have confidence, and are not too sure of their more rational decisions.

Got to be First is "I shop and buy cool". A consumer will tend to feel happy to be the first buyer, and will be proud if he can convey to friends or share on social media. With the findings that the aspect of Got to be First has no effect on the decision to buy indie brands, it can explain consumers' distrust of being the first buyer. Evidenced by the results of the questionnaire response on the Got to be First instrument, the response rate is very small. It is interesting to study further whether being a first buyer and then uploading on social media to get a review response or even himself will submit a review is not a priority? Because if investigated, actually millennials are very narcissistic and love to upload selfies on social media to be seen by others, but in fact these findings say otherwise. 
Want some fun. It can be said that shopping as a desire to have fun is also not proven, even the results of the response are also low. So that it looks as if millennials are rational buyers, that shopping activities are something that requires rational consideration. It is possible that millennials consider the financial aspects, because they are at an early age of work or a career.

Avoid remorse is in shopping, consumers prefer the easiest to buy and can be trusted. Although there is no significant effect, the results of the questionnaire response are high. This can be explained that millennial consumers are not trivial in buying, meaning that they continue to consider rationally, and prioritize products that can be trusted, but the brand trust still depends on the results of investigations on the opinions of others.

Decision Anxiety is in choosing a local indie brand product, consumers often feel confused because there are so many choices, and finally consumers just buy it randomly. This variable gets very low response results. This proves that millennial consumers do not like to buy randomly and carelessly, it can be said that in deciding on purchases, they still consider many things.

I am special, consumers like the unique and special local indie brand products. Although this aspect has no significant effect, the response results show high results. It can be explained that millennial consumers are not too concerned with unique and special products in their purchasing decisions, but still like the unique and special products. So they just like it, but don't buy. Maybe prefer the popular not the special one.

Buy and $\mathrm{Be}$ One is a consumer get easily frustrated when shopping because they don't get why they need all these extra ways to shop. In this case the findings indicate that Buy and Be One has no significant effect. There is a reason that in buying local indie brand products, millennials do not like spending too much time searching for information, and they immediately buy and use it. So, millennial consumers do not like the hassle of spending time searching and finding the desired product, and also do not want to rush into buying for immediate use. Millennial consumers do not want to be frustrated because they are struggling. That's why they trust the results of the users who have used it first.

In the digital era like today, millennial uses all three types of information: they clearly prefer products with better attributes and with higher average consumer ratings. In making difficult choices between product attributes, most millennials choose products with a higher review. However, preferences for products that are ranked higher can be overwritten by a negative or positive review that positively impacts purchases. Unlike older adults, they do not consider collected consumer information and positive reviews that 
focus on positive experiences with the product, but are easily swayed by reviews that report negative experiences [8].

\section{Conclusion and Suggestions}

Therefore, to marketers in this digital age, handling all customer feedback with service excellence in mind, enables a positive experience. Mastery of the internet and social media by Indie brand players has leveled the market. Big brands have spent money on marketing and previously had the upper hand, but now with consumers having voice on the internet and social media, making indie brands easier to compete. Reviews on the internet and social media are instantaneous and available to consumers to make purchasing decisions. Indie brands that think about how people shop will always be winners. Now everyone needs to look at reviews. Marketing is all about consumer reviews.

Competition between top brands and independent brands known as indie brands has won the hearts of consumers, because they are considered to have more emotional closeness with consumers. Marketing of local indie brands needs to focus on consumers who like local touches but have global tastes, and some consumers who are loyal to traditional products. The key to success is to concentrate on the benefits that consumers feel in their local markets. In the face of aggressive and established big and foreign competitors, indie brands often feel the need to improve their products and services for their customers' special and often unique needs. Indie brands must resist the temptation to try to reach all customers or imitate multinational companies. Indie brands will be able to do better by focusing on consumers who value local touch and ignore those who like global brands.

\section{Acknowledgment}

The authors would like to thank the vice chancellor of Universitas Negeri Surabaya, Deputy of teaching and learning, and the Economics Faculty for supporting the funding of this research.

\section{References}

[1] Startup Rangking. Countries. Retrieved from: www.startuprangking.com (accessed on October 25, 2018). 
[2] Public Relations of the Ministry of Cooperations and SMEs. Ratio wirausaha indonesia naik jadi 3,1 persen (Indonesian entrepreneurs ratio increases to 3.1\%), the Ministry of Cooperations and SMEs. Retrieved from: www.depkop.go.id/content/read/ratiowirausaha-indonesia-naik-jadi-31-persen (accessed on October 23, 2018).

[3] Das, K., Gryseels, M., Sudhir, P., et al. (2016). Unlocking Indonesia's Digital Opportunity.

[4] SMITH. Exclusive report: Emotional drivers of purchase decision. Retrieved from: http://smith.co/assets/docs/SMITH-POV-8-modes-of-shopping-report.pdf (accessed November 2014).

[5] Newman, M. Z. (2009). Indie culture: In pursuit of the authentic autonomous alternative. Cinema Journal, vol. 48, no. 3.

[6] Luvaas, B. (2013). Third world no more: Rebranding Indonesian streetwear. Fashion Practice, vol. 5, no. 2, pp. 203-228.

[7] Kotler, P. and Keller, K. L. (2012). Marketing Management (fourteenth edition). New Jersey: Prentice Hall.

[8] Helversen, B., Abramczuk, K., Kopeć, W., et al. (September 2018). Influence of consumer reviews on online purchasing decisions in older and younger adults. Decision Support Systems, vol. 113, pp. 1-10. 